\title{
STRUKTUR KOMUNITAS DAN POLA SEBARAN ZOOPLANKTON DI PERAIRAN DESA SAWAPUDO KECAMATAN SOROPIA KABUPATEN KONAWE
}

\section{Community Structure and Distribution Patterns of Zooplankton in Sawapudo Waters of Soropia Sub-district of Konawe Regency}

\author{
Lilis $^{1}$, WaNurgayah ${ }^{2}$, dan Nur Irawati ${ }^{2}$ \\ ${ }^{1}$ Mahasiswa Jurusan Ilmu Kelautan, \\ Fakultas Perikanan dan Ilmu Kelautan, Universitas Halu Oleo. \\ J1. H.E.A Mokodompit Kampus Hijau Bumi Tridharma Anduonohu Kendari 93232, Telp/Fax: (0401) 3193782 \\ ${ }^{2}$ Surel : nurgayah_fish@yahoo.com \\ ${ }^{2}$ Surel : nur_irawati78@yahoo.com
}

\begin{abstract}
Abstrak
Zooplankton merupakan salah satu komponen dalam rantai makanan dalam kaitannya dengan produktivitas suatu ekosistem. Hal ini dikarenakan zooplankton berperan ganda sebagai baik konsumen level satu maupun level dua, yang juga menjadi rantai penghubung pada plankton dan nekton. Penelitian ini bertujuan untuk mengetahui Struktur Komunitas dan Pola Sebaran Zooplankton Di Perairan Desa Sawapudo, Kecamatan Soropia, Kabupaten Konawe. Penentuan stasiun sampling menggunakan metode purposive sampling. Pengolahan data meliputi Komposisi Jenis, Kelimpahan, Indeks Keanekaragaman, Indeks Keseragaman, Indeks Dominansi, dan Indeks Morisita. Parameter perairan yang terukur ialah suhu, salinitas, kescerahan, kecepatan arus, derajat keasaman $(\mathrm{pH})$, dan intensits cahaya. Hasil kelimpahan rata-rata zooplankton berkisar antara 31-50 ind/L pada pukul 06.00-07.00, 28-42 ind/L pada pukul 12.0013.00 dan 30-51 ind/L pada pukul 18.00-19.00. Nilai indeks keanekaragaman berkisar antara 1,05 1,26; indeks keseragaman 0,75-0,88; dan indeks dominansi 0,06-0,21. Berdasarkan penelitian diperoleh hasil sebaran zooplankton seragam pada ketiga stasiun penelitian. Hasil peneltian menunjukan jenis zooplankton yang mendominasi perairan Sawapudo dari genus Copepoda, Nauplius, dan Tortanus sp. dari kelas Crustacea.
\end{abstract}

Kata Kunci : Perairan Sawapudo, Struktur Komunitas, Pola Distribusi, Zooplankton

\begin{abstract}
Zooplankton is one component in the food chain concerning the productivity of an ecosystem. This is because zooplankton can play a dual role as level one and level two consemers, which are also intermediaries for plankton and nekton. This study aims to determine the Structure Of Comunity And Zooplankton Distribution In Sawapudo Waters, Soropia District, Konawe Regency. The sampling stasion is determined by using the purposive sampling method. Data processing was done to obtain Species Compocition, Abundance, Diversity Index, Uniformity Index, Doinance Index, And Morisita Index. The water parameters measured are temperature, salinity, brightness, current speed, acidity $(\mathrm{pH})$, and light intensity. Based on the results, an abundance of zooplankton was the range of 31-50 ind/L. Then, at the time of 06.00-07.00 and 12.00-13.00, there were the abudance of zooplankton at $28-42 \mathrm{ind} / \mathrm{L}$ and $30-51 \mathrm{ind} / \mathrm{L}$, respectively. Moreover, the value of the diversity index was found between 1,05 and 1,26 , the uniformity index $(0,75-0,88)$, and dominance index $(0,06-0,21)$. it could be concluded, zooplankton found uniformly at all research stasions. On the other hand, the type of zooplankton that dominates the waters of sawapudo came from the Genera of Copepoda, Nauplius, and Tortanus sp. in the crustacean class.
\end{abstract}

Keywords : Sawapudo Waters, Community Structure, Distribution Patterns, Zooplankton

\section{Pendahuluan}

Wilayah perairan merupakan kawasan yang sangat penting untuk berbagai keperluan dan aktifitas dalam bidang perikanan, pariwisata, industri dan sebagainya. Suatu perairan laut dapat dikatakan kaya akan sumberdaya perairan jika perairan tersebut memiliki kesuburan yang tinggi yang dapat dilihat dari produktifitas perairannya antara lain plankton, nutrien dan bentos (Fitriya N,dkk, 2011).
Plankton merupakan biota air yang umum digunakan sebagai bioidikator, karena keanekaragamannya sangat dipengaruhi oleh faktor - faktor lingkungan. Plankton adalah suatu organisme pokok yang penting di dalam eklogi laut, yang hidupnya melayang layang atau mengapung di perairan baik laut maupun tawar. Plankton merupakan makanan alami bagi larva organisme peraian. Pada dasarnya Plankton terbagi menjadi dua 
kelompok yakni fitoplankton (tumbuhan) dan zooplankton (Hewani).

Zooplankton merupakan organisme air yang memiliki peranan sebagai konsumen tingkat pertama yang memakan fitoplankton, selanjuntnya zooplankton dimakan oleh organisme lain yang lebih tinggi tingkatannya dalam rantai makanan. Zooplankton merupakan organisme penting dalam proses pemanfaatan dan perpindahan energi. Zooplankton juga berperan penting dalam membawa karbodioksida ke dalam air, karena mereka dapat berimigrasi dari atas ke bawah. Zooplankton merupakan biota yang sangat penting peranannya dalam rantai makanan, karena menjadi kunci utama dalam transfer energi dari produsen utama ke konsumen pada tingkatan pertama dalam trofik ekologi. Oleh karena itu, kehadirannya di suatu perairan dapat menggambarkan karakteristik suatu peraian. Sebagai herbivora primer di ekosistem perairan, peranan zooplankton sangat penting karena dapat mengontrol kelimpahan fitoplankton. Struktur komunitas dan pola sebaran zooplankton dapat diajadikan sebagai salah satu indikator biologi dalam menentukan perubahan kondisi perairan.

Perairan Sawapudo yang berlokasi di Desa Sawapudo Kecamatan Soropia, memiliki kekayaan sumber daya hayati yang melimpah untuk mendukung kehidupan masyarakat setempat. Diantaranya; ekosistem mangrove, lamun dan terumbu karang yang menjadi tempat tinggal dan mencari makan bagi berbagai jenis biota yang berasosiasi di dalamnya, bahkan sebagian dari masyarakat setempat menjadikan perairan ini sebagai sumber mata pencaharian.Sampai saat ini, kegiatan pemanfaatan tersebut masih terus dilakukan bahkan menjadi kegiatan ekonomi utama bagi sebagian masyarakat Desa Sawapudo. Kegiatan tersebut diduga akan memengaruhi keberadaan zooplankton yang hidup diperairan Desa Sawapudo. Oleh karena itu, maka perlu dilakukan penelitian mengeanai Struktur Komunitas dan Pola Sebaran Zoplankton di Perairan Desa Sawapudo untuk melihat struktur kimunitas dan penyebarannya, sedangkan pengukuran kualitas air untuk melihat kondisi lingkungan perairan.

$\begin{array}{ccc}\text { Zooplankton memiliki } & \text { peranan } \\ \text { sebagai konsumen primer dengan }\end{array}$

memanfaatkan sumber energi yang diperoleh fitoplankton. Zooplankton melakukan gerakan vertikal secara berskala dalam rentang waktu tertentu di perairan, pada malam hari zooplankton bergerak kearah permukaan perairan dan menuju pada kedalaman saat cahaya matahari kembali ke perairan pada siang hari. Faktor ketersediaan makanan merupakan salah satu komponen penting terhadap keberadaan zooplankton di suatu perairan. Hubungan ketergantungan antara zooplankton dan fitoplankton adalah sangat erat, kondisi ini dapat membentuk jalur rantai makanan. Fitoplankton di mangsa oleh zooplankton, kemudian zooplankton dimakan oleh ikan-ikan kecil pada tingkat tropik lebih yang tinggi. Sehingga berdasarkan data tersebut perlu dilakukan penelitian untuk memperoleh informasi mengenai Struktur Komunitas dan Pola Sebaran Zooplankton di Perairan Desa Sawapudo Kecamatan Soropia Kabupaten Konawe.

Penelitian ini diharapkan dapat memberikan informasi bagi penelitian selanjutnya mengenai studi keanekaragaman jenis zooplankton di Perairan Desa Sawapudo,Kecamatan

Soropia. Disamping itu, penelitian ini diharapkan dapat menambah wawasan serta menjadi sumber informasi penting mengenai struktur komunitas maupun distribusi zooplankton dan menjadi sumber data mengenai kesuburan Perairan Desa Sawapudo.

\section{Bahan dan Metode}

Pengambilan data penelitian ini telah dilaksanakan pada bulan April - Mei 2018 di Perairan Desa Sawapudo, Kecamatan Soropia, Kabupaten Konawe. Prosedur penelitian meliputi survei pendahuluan, penentuan titik lokasi penelitian, pengambilan data zooplankton, pengukuran parameter lingkungan.

Survei pendahuluan dilakukan untuk melihat apakah aktifitas manusia yang berlangsung di sekitar perairan akan berdampak pada keberadaan zooplankton di perairan Desa Sawapudo. Selain itu survei pendahuluan juga dilakukan untuk mengetahui kondisi ekologi lokasi penelitian secara menyeluh dan untuk menentukan titik stasiun peneltian. 


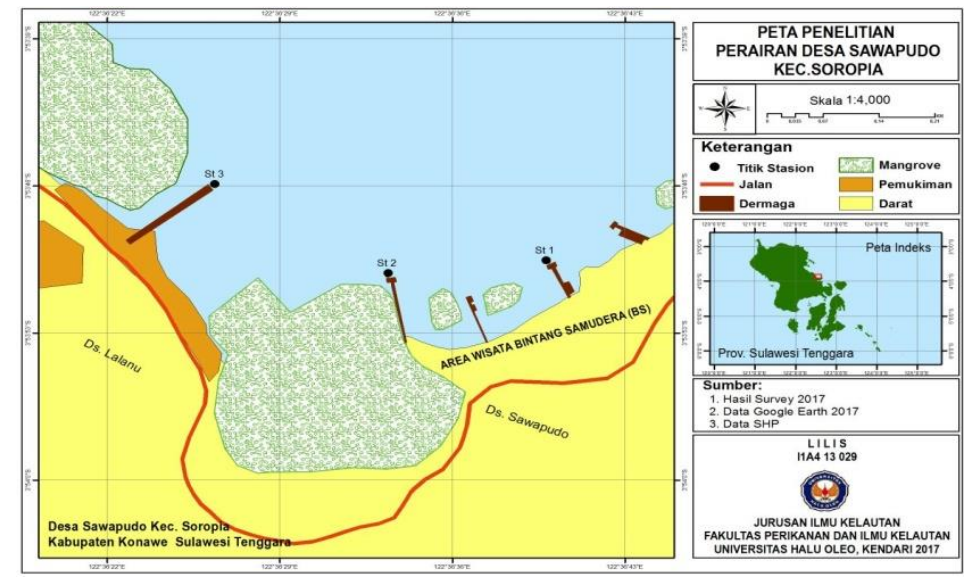

Gambar 1. Peta lokasi penelitian

Setelah melakukan survei pendahulaun, dilakukan penandaan stasiun penelitian menggunakan GPS untuk menandai titik stasiun penelitian yang akan diamati. Penentuan titik stasiun penelitian didasarkan pada pertimbangan bahwa lokasi stasiun yang dipilih dapat mewakili kondisi ekologi Perairan Desa Sawapudo secara keseluruhan.

Lokasi penelitian terbagi atas tiga stasiun pengamatan, stasiun I dan II terletak pada lokasi Taman Wisata Pantai Bintang Samudra. Stasiun III terletak di demaga yang berada di Desa Lalanu, karena tempat ini dimanfaatkan oleh masyarakat untuk kegiatan penangkapan ikan dan tempat berlabuhnya perahu motor. Stasiun I, terlatak pada bagian Selatan Desa Sawapudo dengan titik koordinat $03^{\circ} 53^{\prime} 49$, 58' 'LS $122^{\circ} 36^{\prime} 39,87^{\prime \prime} B T$. Stasiun II, terletak pada bagian Selatan Desa Sawapudo dengan titik koordinat $03^{\circ} 53^{\prime} 50,22^{\prime}$ LS $122^{\circ} 36^{\prime} 33,37^{\prime \prime} B T$. Stasiun III, terletak pada bagian Barat Desa Sawapudo dengan titik koordinat $122^{\circ} 36^{\prime} 26,25^{\prime \prime}$ BT.

Pengambilan sampel zooplankton dari kolom air dilakukan sebanyak tiga kali mulai pada bulan April - Mei. Pengambilan sampel pada pagi hari pukul $06.00-07.00$, siang hari pukul 12.00 - 13.00, dan malam hari pukul 18.00 - 19.00WITA dengan menggunakan plankton net 30 (msh size $35 \mu \mathrm{m})$ dengan panjang jaring $120 \mathrm{~cm}$ dan diameter $30 \mathrm{~cm}$. Sampel zooplankton diperoleh dengan cara menyaring 100 liter air (Fachrul, 2007), pada permukaan perairan $(<1$ meter $)$ dengan menggunakan ember plastik (volume 10 liter) (Nugraha et al., 2008;Nontji, 2008; Gulle et al., 2010). Sampel zooplakton yang tersaring kemudian dimasukan kedalam botol sampel
$30 \mathrm{ml}$ lalu diawetkan dengan cara diberi larutan lugol sebanyak 2-3 tetes. kemudian diidentifikasi di Laboratorium Pengujian Fakultas Perikanan dan Ilmu Kelautan menggunakan mikroskop binokuler. Zooplankton diidentifikasi menggunakan buku identifikasi Yamaji (1982).

Identifikasi zooplankton dilakukan di Laboratorium Pengujian Fakultas Perikanan dan Ilmu Kelautan dengan menggunakan Sedwick Rafter Counting Cell (SRC. Pengamatan dilakukan dibawah mikroskop binokuler dengan pembesaran $10-40 \mathrm{x}$. Pengambilan sampel parameter fisika dan kimia perairan dilakukan di lapangan kemudian dianalisis di Laboratorium Pengujian Fakultas Perikanan dan Ilmu Kelautan Universitas Halu Oleo.

\section{Analisis Data}

Data yang telah diperoleh ditabulasi secara keseluruhan kemudian dianalis untuk mengetahui struktur komunitas dan pola sebaran zooplankton. Komposisi jenis zooplankton dihitung dengan menggunakan formula yang dimodifikasi dari (Fachrul, 2007) sebagai berikut :

$\mathrm{Pi}=\frac{n i}{N} \mathrm{x} 100 \%$

Keterangan :

$\mathrm{Pi}=$ Komposisi spesies $(\%)$

$\mathrm{ni}=$ Jumlah spesies ke $-\mathrm{i}$

$\mathrm{N}=$ Jumlah total spesies

Kelimpahan plankton dihitung dengan metode sensus atau sapuan dengan Sedwick Rafter Cell (SRC) menggunakan formula dari APHA (2005), yaitu :

$\mathrm{K}=\mathrm{N} / \mathrm{Ac} \times \mathrm{At} / \mathrm{Vs} \mathrm{x} \mathrm{Vt} / \mathrm{As}$

Keterangan :

$\mathrm{K}=$ Kelimpahan Plankton (ind $\mathrm{I}^{-1}$ ) 
$\mathrm{N}=$ Jumlah plankton yang diamati

$\mathrm{Ac}=$ Luas amatan $\left(\mathrm{mm}^{2}\right)$

At $=$ Luas penampang permukaan SRC $\left(\mathrm{mm}^{2}\right)$

$\mathrm{Vs}=$ Volume konsentrat dalam SRC (ml)

$\mathrm{Vt}=$ Volume konsentrat botol contoh plankton $(\mathrm{mI})$

As $=$ Volume air disaring $(\mathrm{L})$

Analisis yang digunakan untuk mengetahui keanekaragaman jenis biota perairan. Persamaa yang digunakan untuk menghitung indeks ini adalah persamaan Shanon-Wiener (Basmi, 1998), yaitu :

$\mathrm{H}^{\prime}=-\sum_{\mathrm{i}=2}^{\mathrm{n}} \mathrm{P} i \ln \mathrm{Pi}$

Keterangan :

$\mathrm{H}^{\prime}=$ Indeks keanekaragaman

$\mathrm{Pi}=\mathrm{n} / \mathrm{N}$ proporsi jenis ke- $\mathrm{i}$

$\mathrm{n}=$ jumlah individu jenis ke- $\mathrm{i}$

$\mathrm{N}=$ jumlah total individu

Kriteria penilaian keanekaragaman yakni jika $\mathrm{H}^{\prime}<1$ maka keanekaragaman jenis rendah, jika $1<\mathrm{H}^{\prime}<3$ maka keanekaragaman jenis sedang, dan bila $\mathrm{H}^{\prime}>3$ maka keanekaragaman tinggi.

Untuk mengetahui penyebaran individu tiap genera yang mendominasi maka digunakan indeks keseragaman menurut Krebs (1989), seabagai berikut :

$\mathrm{E}=\frac{\mathrm{H}^{\prime}}{\mathrm{H}^{\prime} \mathrm{maks}}$

Keterangan :

$\mathrm{E}=$ indeks keseragaman

$\mathrm{H}^{\prime}=$ Indeks keanekaragaman

$\mathrm{H}^{\prime}$ maks $=$ In $\mathrm{S}$ ( $\mathrm{S}=$ Jumlah spesies yang ditemukan)

Menurut Pirzan etal, (2005) yang menyatakan bahwa apabila keseragaman mendekati nol berarti keregaman antar spesies di dalam komunitas tergolong rendah dan sebaliknya keseragaman yang mendekati satu dapat dikatakan keseragaman antar spesies tergolong merta atau sama. Sehubungan dengan indeks keseragaman Fahrul (2007), mengemukakan bahwa nlai indeks keseragaman ini berkisar dari $0-1$. Jika indeks keseragaman mendekati $1(>0,5)$ berarti keseragaman organisme dalam suatu perairan berada dalam keadaan seimbang, berarti tidak terjadi persaingan baik terhadap tempat maupun terhadap makanan, sebaliknya jika ndeks keseragaman mendekati $0(<0,5)$.

Indeks dominansi digunakan untuk melihat ada tidaknya suatu jenis tetentu yang mendominasi dalam suatu jenis populasi. Perhitungan indeks dominansi untuk zooplankton menggunakan rumus indeks dominansi Simson (Krebs, 1989) sebagai berikut :

$D=-\sum_{\mathrm{i}=1}^{n}\left(\frac{\mathrm{ni}}{\mathrm{N}}\right)^{2}$

Keterangan :

$\mathrm{D}=$ indeks dominansi simpson

$\mathrm{ni}=$ Jumlah individu spesies ke-i

$\mathrm{N}=$ Jumlah total individu

Nilai D berkisar antara 0 hingga 1 , dimana D semakin mendekati 1 maka semakin besar peranan atau dominansi suatu spesies dalam komunitas.

Untuk pola distribusi zooplankton dihit ung menggunakan indeks morisit menurut Brower dan Ende (1990) dengan rumus:

$$
\mathrm{Id}=n \frac{\sum x^{2}-N}{N(N-1)}
$$

Keterangan :

Id = Indeks Morisita

$\mathrm{X}^{2}=$ Jumlah individu pada tiap stasiun

$\mathrm{n}=$ Jumlah stasiun

$\mathrm{N}=$ Jumlah total individu

Kriteria Pola Sebaran disajikan pada Tabel 1.

Tabel 1. Kriteria Pola Sebaran (Id) (Brower dan Ende, 1990)

\begin{tabular}{cl}
\hline Kisaran & \multicolumn{1}{c}{ Kiteria } \\
\hline $\mathrm{Id}=1,0$ & Pola penyebaran individu acak \\
& $\begin{array}{l}\text { Pola penyebaran individu } \\
\mathrm{Id}<1,0\end{array}$ \\
$\mathrm{seragam}$ \\
$\mathrm{Id}>1,0$ & $\begin{array}{l}\text { Pola penyebaran individu } \\
\text { mengelompok }\end{array}$ \\
\hline
\end{tabular}

\section{Hasil dan Pembahasan}

Komposisi jenis zooplankton yang ditemukan di Perairan Sawapudo berjumlah tujuh kelas zooplankton yang terdiri dari kelas Crustacea (5 jenis), kelas Hexanauplia (4 jenis), kelas Oligotrichea (2 jenis), kelas Monogononta, Favella, Maxillopoda, Brachiopoda dan Ciliatea masing - masing terdiri dari 1 jenis. Kelas Crustacea merupakan zooplankton dengan komposisi tertinggi yang ditemukan dengan persentase rata - rata $31 \%$ pada stasiun I, $42 \%$ pada stasiun II dan $34 \%$ pada stasiun III. Komposisi jenis zooplankton yang terendah ialah darikelas Brachiopoda, Monogononta, Ciliatea dan Maxillopoda yang masingmasing memiliki komposisi sama dengan persentase rata - rata $8 \%$. 


\section{Komposisi Jenis Zooplankton Berdasarkan Kelas Stasiun I}

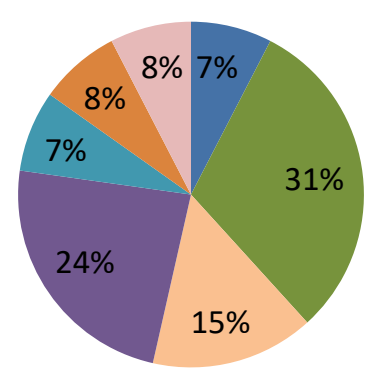

- Ciliatea

- Crustacea

Oligotrichea

- Hexanauplia

- Maxillopoda

Monogononta

Brachiopoada

Gambar 2. Histogram Nilai Komposisi jenis zooplankton stasiun I berdasarkan kelas di Perairan Desa Sawapudo.

\section{Komposisi Jenis Zooplankton Berdasarkan Kelas} Stasiun II

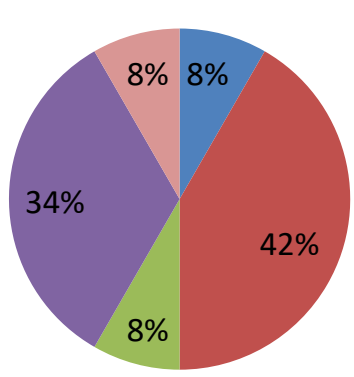

- Ciliatea

- Crustacea

- Oligotrichea

- Hexanauplia

Monogononta

Gambar 3. Histogram Nilai Komposisi jenis zooplankton stasiun II berdasarkan kelas di Perairan Desa Sawapu

\section{Komposisi Jenis Zooplankton Beerdasarkan Kelas} Stasiun III

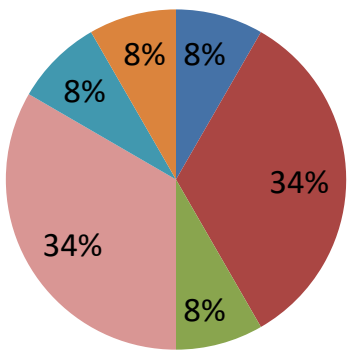

- Ciliatea

- Crustacea

- Oligotrichea

- Hexanauplia

- Maxillopoda

- Brachiopoada

Gambar 4. Histogram Nilai Komposisi jenis zooplankton stasiun III berdasarkan kelas di Perairan Desa Sawapudo 
Tabel 2. Jenis-jenis zooplankton yang ditemukan pada masing-masing Stasiun

\begin{tabular}{|c|c|c|c|}
\hline \multirow{2}{*}{ Jenis-jenis Zooplankton } & \multicolumn{3}{|c|}{ Stasiun } \\
\hline & $\mathbf{I}$ & II & III \\
\hline \multicolumn{4}{|l|}{ Kelas Crustacea } \\
\hline - Copepoda sp. & + & + & + \\
\hline - Temora sp. & - & + & - \\
\hline - Tortanus sp. & + & + & + \\
\hline - Nauplius sp. & + & + & + \\
\hline - Polychaeta sp. & - & + & + \\
\hline \multicolumn{4}{|l|}{ Kelas Hexanauplia } \\
\hline - Oithona sp. & + & + & + \\
\hline - Apocyclopas sp. & + & + & + \\
\hline - Onychocamptus sp. & + & - & + \\
\hline $\begin{array}{l}\text { - Microsetella sp. } \\
\text { Kelas Maxillopoda }\end{array}$ & + & + & + \\
\hline - Balanus sp. & + & - & + \\
\hline \multicolumn{4}{|l|}{ Kelas Oligotrichea } \\
\hline - Codonellopsis sp. & + & - & - \\
\hline - Tintinnopsis sp. & + & + & + \\
\hline \multicolumn{4}{|l|}{ Kelas Ciliatea } \\
\hline - Favella sp. & + & + & + \\
\hline \multicolumn{4}{|l|}{ Kelas Monogononta } \\
\hline - Brachionus sp. & + & - & + \\
\hline \multicolumn{4}{|l|}{ Kelas Brachiopoda } \\
\hline - Aloella sp & + & - & + \\
\hline
\end{tabular}

Keterangan : + : ada; - : tidak ada

Tabel 5. Nilai Indeks Keanekaragaman, Keseragaman dan Dominansi Zooplankton pada Lokasi Penelitian

\begin{tabular}{ccccccccccc}
\hline Waktu & \multicolumn{9}{c}{ Indeks Bilogi } \\
\cline { 2 - 11 } Pengamatan & \multicolumn{2}{c}{$\begin{array}{c}\text { Keanekaragaman } \\
\left(H^{\prime}\right)\end{array}$} & \multicolumn{3}{c}{$\begin{array}{c}\text { Keseragaman } \\
\left(\mathbf{E}^{\prime}\right)\end{array}$} & & \multicolumn{3}{c}{$\begin{array}{c}\text { Dominansi } \\
\left(\mathbf{C}^{\prime}\right)\end{array}$} & \\
\cline { 2 - 11 } & I & II & III & I & II & III & I & II & III \\
\hline $06.00-07.00$ & 1,19 & 1,2 & 1,21 & 0,78 & 0,82 & 0,83 & 0,13 & 0,13 & 0,06 \\
$12.00-13.00$ & $1,26^{*}$ & 1,16 & 1,22 & 0,83 & 0,84 & $0,88^{*}$ & 0,12 & 0,09 & 0,08 \\
$18.00-19.00$ & 1,05 & 1,05 & 1,16 & 0,75 & 0,75 & 0,87 & 0,18 & $0,21^{*}$ & 0,14 \\
\hline
\end{tabular}

Tabel 6. Pola Sebaran Jenis Zooplankton (Id) pada Lokasi Penelitian

\begin{tabular}{ccc}
\hline Waktu & Pola Sebaran (Id) & Kategori \\
Pengamatan & 0,659 & Seragam \\
I & 0,699 & Seragam \\
II & 0,450 & Seragam \\
\hline
\end{tabular}


Komposisi jenis zooplankton berdasarkan kelas yang ditemukan selama penelitian (Gambar 2, 3 dan 4) terdiri dari 7 kelas yakni Crustacea dengan persentase $31 \%$, pada stasiun I, $42 \%$ pada stasiun II, dan $34 \%$ pada stasiun III. kelas hexanauplia memiliki persentase rata-rata $24 \%$ pada stasiun I, 34\% stasiun II dan 34\% pada stasiun III, sedangkan kelas oligotrichea, kelas ciliatea, kelas monogononta, kelas maxillpoda dan kelas brachiopoda memiliki komposisi yang sama dengan persentase $8 \%$ pada stasiun I, stasiun II dan stasiun III. Berdasarkan hasil penelitian terlihat bahwa kelas Crustacea banyak ditemukan pada perairan Desa Sawapudo dengan rata-rata persentase dari ketiga stasiun yakni $31 \%$ pada stasiun I, $42 \%$ staiun II dan $34 \%$ pada stasiun III, sedangkan untuk komposisi terendah salah satunya dari kelas Ciliatea dengan persentase yang sama pada ketiga staiun yakni $8 \%$. Hal ini sejalan dengan pernyataan Nybaken (1992) yang menyatakan bahwa zooplankton di laut didominasi oleh sub klas Copepoda dari kelas Crustacea. Hasil penelitian Wa Atu (2004) pada lokasi budidaya kerang mabe (Pteriapenguin) didapatkan jenis zooplankton yang terdiri dari dua kelas yaitu kelas Crustacea dan Radiolaria, dimana komposisi jenis zooplankton pada lokasi tersebut didominasi oleh kelas Crustacea. Odum (1993) menyatakan bahwa komunitas zooplankton umumnya didominasi oleh kelas crustacea, baik individu maupun jenisnya.

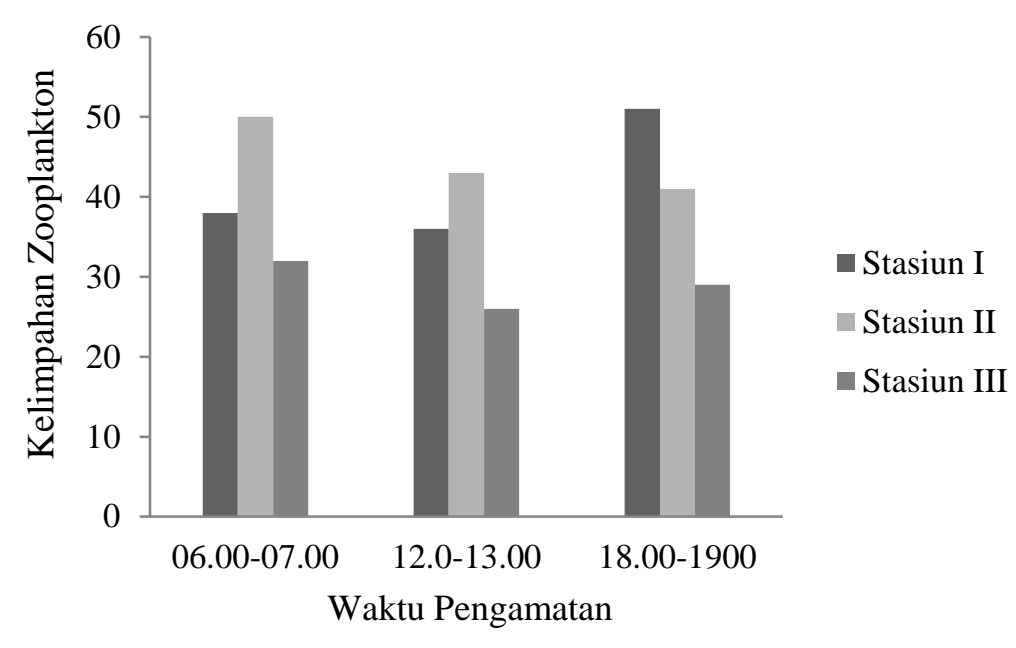

Gambar 5. Histogram Nilai Kelimpahan Zooplankton di Perairan Desa Sawapudo

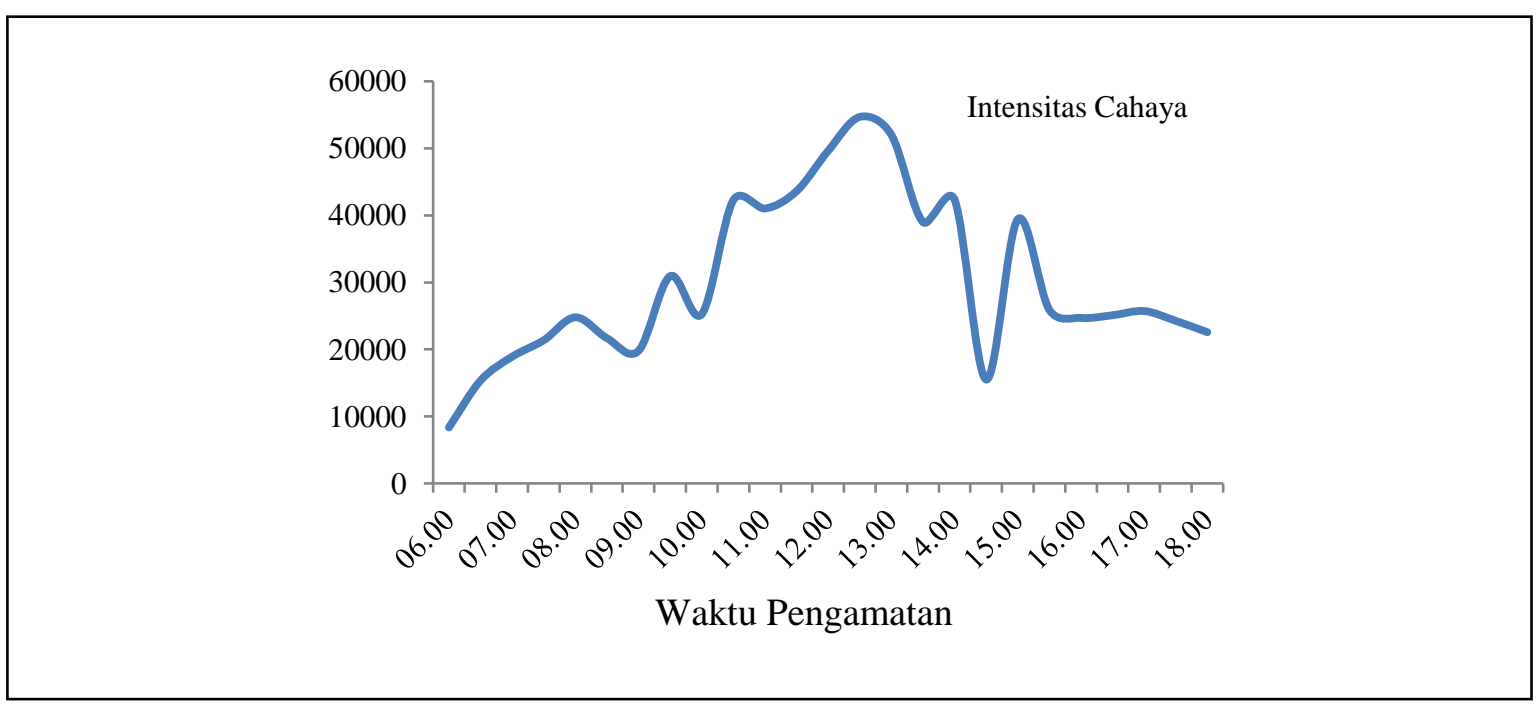

Gambar 6. Histogram Nilai Intensitas Cahaya Selama Penelitian di Perairan Desa Sawapudo 
Tabel 7. Paramter Fisika dan Kimia Perairan

\begin{tabular}{|c|c|c|c|c|c|}
\hline \multirow{2}{*}{ No } & \multirow{2}{*}{ Parameter } & \multirow{2}{*}{$\begin{array}{c}\text { Waktu } \\
\text { Pengamatan }\end{array}$} & \multicolumn{3}{|c|}{ Stasiun } \\
\hline & & & I & II & III \\
\hline \multirow[t]{3}{*}{1} & Suhu ${ }^{\circ} \mathrm{C}$ & $06.00-07.00$ & 28 & 29 & 28 \\
\hline & & $12.00-13.00$ & 29 & 30 & 30 \\
\hline & & $18.00-18.00$ & 28 & 29 & 29 \\
\hline \multirow[t]{3}{*}{2} & Kec. Arus (m/det) & $06.00-07.00$ & 0,04 & 0,05 & 0,04 \\
\hline & & $12.00-13.00$ & 0,05 & 0,06 & 0,06 \\
\hline & & $18.00-18.00$ & 0,05 & 0,06 & 0,05 \\
\hline \multirow[t]{3}{*}{3} & Kecerahan $(\mathrm{cm})$ & $06.00-07.00$ & 3,5 & 3,4 & 4,15 \\
\hline & & $12.00-13.00$ & 6 & 6 & 5,3 \\
\hline & & $18.00-18.00$ & 3 & 4,15 & 3,4 \\
\hline \multirow[t]{3}{*}{4} & Salinitas (ppt) & $06.00-07.00$ & 31 & 31 & 31 \\
\hline & & $12.00-13.00$ & 30 & 30 & 30 \\
\hline & & $18.00-18.00$ & 30 & 30 & 29 \\
\hline \multirow[t]{3}{*}{5} & $\mathrm{pH}$ & $06.00-07.00$ & 7 & 7 & 7 \\
\hline & & $12.00-13.00$ & 7 & 7 & 7 \\
\hline & & $18.00-18.00$ & 7 & 7 & 7 \\
\hline \multirow[t]{3}{*}{6} & Fitoplankton (ind/L) & $06.00-07.00$ & 154 & 82 & 70 \\
\hline & & $12.00-13.00$ & 84 & 56 & 68 \\
\hline & & $18.00-18.00$ & 96 & 105 & 67 \\
\hline
\end{tabular}

Jenis zooplankton yang memiliki komposisi jenis tertinggi pada ketiga stasiun penelitian ialah spesies Copepoda sp. dan Nauplis sp. dari kelas Crustacea. Hal ini disebabkan karena Copepoda sp . merupakan herbivora utama alami di perairan laut. Menurut Nybakken (1992) menyatakan bahwa Copepoda sp. berperan sebagai mata rantai yang amat penting antara produksi primer fitoplankton dengan karnivora kecil. Wardana ( 1986) mengemukakan bahwa di perairan laut banda kisaran komposisi jenis Crustacea di laut seram berkisar antara 59,15\%-79,79\%. Menurut penelitian Harianto (1999) dalam periode pasang maupun periode surut komposisi jenis zooplankton didominasi oleh spesies dari kelas Crustacea.

Tingginya komposisi jenis kelas Crustacea di ketiga stasiun penelitian disebabkan oleh kemampuan untuk mentoleransi terhadap perubahan kondisi lingkungan perairan yang berubah-ubah. Hal ini sesuai dengan pernyataan Pranoto dkk (2005) menyatakan tingginya komposisi Crustacea di perairan karena umumya bersifat euryhalin, lebih mampu bertahan dengan salinitas yang luas yaitu berkisar 934 ppt. Humaira dkk (2016) mengemukakan bahwa tingginya jenis Crustacea yang ditemukan dikarenakan jenis Crustacea dapat toleran atau mampu beradaptasi terhadap perubahan lingkungan. Crustacea merupakan kelas dari zooplankton yang bersifat kosmopolit. Menurut Nastiti dan Hartati (2013) bahwa peran Crustaceae dalam ekosistem pelagis sangat penting dari sudut pandang trofik, sebagai penghubung antara produksi primer dan larva ikan dan juvenile yang mencirikan produksi sekunder laut karena laju pertumbuhan dari Crustaceae relative sangat cepat sehingga kelimpahannya lebih tinggi dibandingkan jenis/kelompok zooplankton lainnya.

Berdasarkan hasil penelitian (Gambar 5) diperoleh nilai kelimpahan rata-rata zooplankton selama periode penelitian berkisar antara $32-50$ ind/L pada pukul $06.00-07.00$, sedangakan pada pukul 12.00 13.00 berkisar antara $26-43$ ind/L, dan pada pukul 18.00-19.00 berkisar antara 29-51 ind/L. Nilai kelimpahan ini sejalan dengan penelitian yang dilakukan Umar et al (2009) yang menyaring 80 liter air laut dengan 
menggunakan planktonet bertingkat $35 \mu$ dan $50 \mu \quad$ kelimpahan zooplankton yang ditemukan berkisar antara 22-499 ind/L termasuk dalam kelimpahan zooplankton yang rendah.

Tingginya kelimpahan zooplankton di stasiun II dan stasiun I pada pukul 06.0007.00 dan pada pukul 18.00-19.00 WITA salah satunya dikarenakan keberadaan fitoplankton sebagai sumber makanan utama bagi zooplankton berbanding lurus dengan tingginya kelimpahan zooplankton, selain itu rendahnya nilai intensitas cahaya matahari pada saat pengambilan sampel relatif rendah (teduh) sehingga zooplankton cenderung mendekati permukaan perairan. Hal ini sejalan dengan penelitian Susanti (2010) menyatakan bahwa nilai kelimpahan zooplankton yang tinggi kemungkinan dipengaruhi oleh keberadaan fitoplankton, dimana keberadaan fitoplankton di dalam perairan dapat memengaruhi keberadaan zooplankton dalam rantai makanan.

Zooplankton yang bersifat herbivor memakan fitoplankton secara langsung, sedangkan secara tidak langsung zooplankton yang bersifat karnivora memakan zooplankton lain yang bersifat herbivor atau karnivora lain yang umumnya mempunyai ukuran tubuh yang lebih kecil. Hal ini sejalan dengan pernyataan Nyabakken (1992) yang menyatakan bahwa intensitas cahaya matahari dapat menyebabkan respon negatif bagi organisme yang melakukan migrasi. Zooplankton akan bergerak menjauhi permukaan perairan apabila intensitas cahaya matahari meningkat dan mendekati permukaan apabila intensitas cahaya matahari menurun. Selain intensitas cahaya matahari dikarenakan keadaan suhu perairan yang normal yaitu berkisar $29-30^{\circ} \mathrm{C}$. juga memengaruhi kelimpahan zooplankton. Hal ini sejalan dengan pernyataan Ambiasa (2007) menyatakan suhu air yang baik bagi kelangsungan hidup dan perkembangan plankton berkisar antara $20-30^{\circ} \mathrm{C}$.

Menurut Manigasi (2013), suhu perairan memengaruhi keberadaan zooplankton secara fisiologis dan ekologis. Secara fisiologis, perbedaan suhu perairan sangat berpengaruh terhadap umur dan ukuran zooplankton dewasa. Secara ekologis, perubahan suhu menyebabkan perbedaan komposisi dan kelimpahan zooplankton. Sedangkan faktor yang menyebabkan rendahnya kelimpahan zooplankton pada stasiun III pukul 12.00-13.00 ialah kecepatan arus yang cepat yakni $0,06 \mathrm{~m} / \mathrm{det}$. Selain kecepatan arus yang tinggi, pola migrasi vertikal harian zooplankton juga memicu kurangnya pertumbuhan atau keberadaan zooplankton. Hal ini didukung oleh Lasri dkk, (2013) yang menyatakan bahwa kecepatan arus merupakan parameter penting sehubungan dengan keberadaan zooplankton, arus yang kencang dapat memengaruhi distribusi fitoplankton pada suatu perairan sehingga secara tidak langsung juga berpengaruh pada keberadaan zooplankton. Susanti (2010) yang menyatakan bahwa distribusi zooplankton secara vertikal tergantung dari pergantian musim dan hubungan keberadaan kelompok. Apabila perairan menjadi lebih dingin, maka zooplankton akan naik keatas karena lapisan ini miskin oksigen.

Kelimpahan zooplankton terbanyak ditemukan dari kelas Crustacea dari jenis Copepoda, Tortanus, Nauplius, polychaeta dan temora sp. Kelimpahan spesies tertinggi dari jenis copepoda sp. hal ini dikarenakan copepoda sp. dapat bertahan hidup dengan baik dalam berbagai habitat. Selain itu kelimpahan zooplankton juga dipengaruhi oleh migrasi vertikal harian, yaitu ke arah dasar pada siang hari bila intensitas cahaya dilapisan permukaan meningkat dan ke arah lapisan permukaan laut pada malam hari. Hal ini sejalan dengan pernyataan Setiawati (2017) yang menyatakan bahwa melimpahnya keberadaan copepoda di perairan ialah disebabkan copepoda dapat bertahan hidup dengan baik dalam berbagi habitat, copepoda mampu bertahan pada perubahan kondisi lingkungan yang ekstrim seperti pada suhu $17-30^{\circ} \mathrm{C}$ dan $\mathrm{pH}$ delapan. Ferdous dan Mutakdir (2009) yang menyatakan bahwa diantara semua zooplankton, copepoda memiliki exoskeleton terberat dan terpanjang serta pelengkap terkuat yang membantu mereka untuk bergerak lebih cepat dibandingkan zooplankton jenis lainnya. Nyabaken (1992) menyatakan bahwa Copepoda dari ordo Calanoida dan Harpactionida adalah zooplankton berukuran kecil yang mendominasi diseluruh perairan bahari. Ditambhakan oleh Sachlan (1972) bahwa dalam ekosistem perairan, copepoda merupakan zooplankton yang dominan 
dengan populasi yang mencapai $70-80 \%$. Davis (1995) menyatakan rangsangan utama yang mengakibatkan dimulainnya gerakan vertikal harian adalah cahaya. Cahaya mengakibatkan respon negatif bagi zooplankton yang melakukan migrasi. Zooplankton bergerak menjauhi lapisan permukaan apabila intensiatas cahaya di lapisan permukaan meningkat. Sebaliknya mereka akan bergerak ke arah lapisan permukaan laut bila intensitas cahaya di lapisan permukaan menurun. Karuwal (2015) menyatakan bahwa gerakan naik turunnya zooplankton secara berskala atau dikenal dengan migrasi vertikal harian ini dapat menyebabkan perbedaan kelimpahan dan komposisi zoopankton antara lapisan dasar dan permukaan dari suatu perairan. Sulawesty (2005) mengemukakan bahwa pola kelimpahan zooplankton dipengaruhi oleh faktor-faktor ketersediaaan makanan, tekanan predasi dan kondisi hidrologi perairan.

Kelimapahan zoopalankton mengalami kenaikan dan penurunan dapat disebabkan oleh beberapa faktor seperti pertumbuhan, kematian, distribusi vertikal, migrasi dan perubahan kualitas periaran. Hal ini sejalan dengan pernyataan Kenish (1990) bahwa kelimpahan zooplankton mengalami kenaikan dan penurunan disebabkan oleh faktor dari masing - masing zooplankton itu sendiri, seperti : pertumbuhan, kematian, migrasi yang berbeda, distribusi vertikal, dan perubahan kualitas air dari waktu ke waktu. Selain itu adanya pemangsaan (grazing) dari zooplankton karnivora dan predator zooplankton diduga juga memengaruhi kelimpahan zooplankton di perairan tersebut. Sumich (1992) menyatakan bahwa kelimpahan zooplankton dipengaruhi oleh beberapa faktor lain yaitu salinitas, intensitas cahaya, suhu, ketersediaan makanan, dan predator.

Berdasarkan hasil indeks keanekaragaman (H') zooplankton selama penelitian (Tabel. 3) berkisar antara 0,051,26. Nilai rata-rata indeks keanekaragaman tertinggi terdapat pada stasiun I pukul 12.00 yakni 1,21 sedangkan yang terendah terdapat pada stasiun I pukul 18.00-19.00 yakni 1,05. Nilai indeks keanekaragan berdasarkan kisaran dan rata-rata tiap stasiun pengamatan menunjukan keanekaragaman yang rendah. Hal ini sesuai dengan penelitian Wulandari
(2009) di Perairan Sungai Brantas, bahwa nilai indeks keanekaragaman $\left(\mathrm{H}^{\prime}\right)$ berkisar antara 0,56 - 1,63. Berdasarkan kisaran tersebut nilai keanekaragaman Perairan Sungai Brantas secara umum tergolong dalam klasifikasi perairan yang memiliki keanekaragaman rendah. Hidayat (2017) menyatakan nilai indeks keanekaragaman fitoplankton berkisar antara 1,9115 -2,0932. Berdasarkan kisaran itu, keanekaragaman dan kestabilan fitplankton berada pada kategori rendah karena berada dalam kisaran nilai indeks antara $\mathrm{H}^{\prime}<2,30$. Hal ini dapat diartikan bahwa keberadaan zooplankton tidak berada dalam kondiasi petumbuhan yang optimal untuk berkembang. Selain itu kondisi parameter lingkungan secara umum tidak dalam rentang yang optimal dalam mendukung pertumbuhannya, namun masih dianggap layak dan sesuai. Indeks keanekaragaman di lokasi penelitian termasuk rendah, diduga karena kelimpahan di tiap stasiun tidak merata. Arinardi $d k k$ (1997) menjelaskan bahwa kelimpahan individu dari masing - masing spesies yang tidak merata menyebapkan rendahnya keanekaragaman.

Berdasarkan hasil analisis indeks keseragaman (E') zooplankton selama penelitian (Tabel. 3) berkisar antara 0,750,88 . Nilai rata-rata indeks keseragaman tertinggi terdapat pada stasiun III pukul 18.00-19.00 yakni 0,88 , sedangkan niali indeks keseragaman terendah terdapat pada stasiun I dan II yakni 0,75. Nilai indeks keseragaman berdasarkan rata - rata tiap stasiun menunjukan pada stasiun I, II, dan III nilai indeks mendekati 1 berarti keseragaman zooplankton antar spesies relatif merata. Hal ini sesuai dengan pernyataan Fachrul (2007), mengemukakan bahwa nilai indeks keseragaman ini berkisar dari $0-1$. Jika indeks keseragaman mendekati $1 \quad(>0,5)$ berarti keseragaman organisme dalam suatu perairan berada dalam keadaan seimbang, berarti tidak terjadi persaingan baik terhadap tempat maupun terhadap makanan, sebaliknya jika indeks keseragaman mendekati $0 \quad(<0,5)$. Sejalan dengan penelitian Hutabarat dkk (2013) pada Perairan Sungai Babon, menemukan bahwa nilai keseragaman (E') rata - rata berkisar 0,822-0,964 atau mendekati 1 berarti keseragaman plankton antar spesies relatif merata atau jumlah individu masing-masing 
spesies relatif sama. Peristiwady \& La Pay (2012) menyatakan kategori nilai indek keseragaman (E') yaitu apabila nilai $0,00<$ $\mathrm{E}<0,50$ komunitas dalam kondisi tertekan, nilai $0,50<\mathrm{E}<0,75$ komunitas dalam kondisi labil dan nilai $0,75<\mathrm{E}<1,00$ komunitas dalam kondisi stabil.

Berdasarkan indeks dominansi (C') zooplankton selama penelitian (Tabel. 3) berkisar antara 0,06-0,21. Nilai rata-rata indeks dominansi tertinggi terletak pada stasiun II pukul 12.00-13.00 yakni 0,21 sedangkan yang terendah terdapat pada stasiun III pukul 06.00-07.00 yakni 0,06. Nilai indeks dominansi berdasarkan rata-rata tiap stasiun atau minggu pengamatan menunjukan pada stasiun I, II dan III nilai indeaks dominansi mendekati 0 , sehingga tidak adanya jenis tertentu yang mendominasi perairan tersebut. Hal ini sesuai dengan pernyataan Basmi (2000) apabila nilai indeks dominandi mendekati 0 , berarti di dalam struktur komunitas biota yang diamati tidak terdapat genus yang secara ekstrim mendominasi genus lainnya. Hal ini menunjukan bahwa kondisi struktur komunitas tidak mengalami tekanan ekologis yang berat terhadap biota di habitat tersebut.

Berdasarkan perhitungan dengan menggunakan indeks morisita diperoleh nilai penyebaran zooplankton yakni 0,45-0,69. Hal ini menunjukan bahwa penyebaran jenis zooplankton di lokasi penelitian cenderung seragam atau merata (id $<1,0)$, artinya pola penyebaran zooplankton terjadi secara merata pada ketiga stasiun penelitian, dengan kata lain mempunyai kelimpahan yang berfluktuasi. Hal ini menunjukan bahwa zooplankton yang ditemukan selama pengamatan mampu beradaptsi pada perubahan lingkungan yang terjadi. Odum (1993) mengungkapkan bahwa pola penyebaran secara acak relatif jarang terjadi secara alami dan biasanya terjadi hanya bila kondisi lingkungan sangat seragam dan tidak ada tekanan terhadap populasi.

Pola penyebaran mengelompok dengan tingkat pengelompokan yang bermacammacam merupakan bentuk penyebaran yang paling umum terjadi, karena individuindividu dalam populasi cenderung membentuk kelompok dalam berbagai ukuran. Pola pengelompokan terjadi sebagai akibat dari adanya perbedaan habitat secara lokal. Hal ini sesuai dengan pernyataan
Michael (1997) yang menyatakan bahwa pola penyebaran suatu organisme akuatik dipengaruhi oleh sifat fisika kimia yang memengaruhi kehidupan dan sebaran zooplankton di laut seperti suhu, cahaya matahari, salinitas, oksigen terlarut (DO), derajat keasaman $(\mathrm{pH})$, kecerahan dan arus. Selain sifat-sifat fisika kimia perairan, sebaran juga dipengaruhi oleh daur pembiakan, tingkah laku spesies dalam populasi dan persaingan diantara spesies.

Pola sebaran zooplankton juga dipengaruhi oleh keberadaan fitoplankton dan kualitas lingkungan bagi zooplankton. Hal ini sesuai dengan pernyataan Prasetyati (2004) yag menyatakan bahwa pola distribusi zooplankton dipengaruhi ketersediaan makanan dan kualitas lingkungan. Makanan zooplankton utamanya adalah fitoplankton, namun pada kondisi tertentu zooplankton dapat memanfaatkan bakteri detritus.

\section{Simpulan}

Berdasarkan hasil penelitian maka dapat disimpulkan bahwa :

1. Komposisi jenis zooplankton yang ditemukan di Perairan Sawapudo berjumlah tujuh kelas dengan komposisi jenis tertinggi berasal dari kelas Crustacea yakni $31 \%$ pada stasiun I, $42 \%$ pada stasiun II dan $34 \%$ pda stasiun III. dengan jenis diantaranya Copepoda, Temora, Tortanus, Nauplius, dan Polychaeta sp. Sedangkan komposisi jenis terendah salah satunya berasal dari kelas Monogononta yakni 8\% dengan jenis Brachionus.

2. Kelimpahan tertinggi zooplankton terdapat pada pukul 06.00-07.00 yakni 32-50 ind/L dan pukul 18.00-19.00 yakni 29-51 ind/L pada stasiun II.

3. Nilai indeks keanekaragaman (H') menunjukkan keanekaragaman dan kestabilan zooplankton berada pada kategori rendah. Selanjutnya, nilai indeks keseragaman (E') menunjukkan bahwa jumlah individu tiap jenis zooplankton adalah sama/merata. Kemudian, nilai indeks dominansi (D) menunjukkan bahwa tidak ada jenis zooplankton yang mendominasi selama penelitian.

4. Sebaran zooplankton yang ditemukan selama penelitian ialah penyebaran secara seragam di setiap stasiun pengamatan. 


\section{Daftar Pustaka}

Ambiasa, I.K. 2007. Distribusi spasial fitoplankton dan zooplankton di Teluk Jakarta. Skripsi. Fakultas Perikanan dan Ilmu Kelautan. IPB. Bogor : 80 hal.

(APHA) American Public Health Association. 2005. Standard Methods for the Examination of Water and Wastewater. $21^{\text {th }}$ Edition. Washington DC (US): American Public Health Assosiation American Water Work Association/Water Enviroment Federation.

Arinardi, O.H., A.B. Sutomo., S.A. Yusuf., Tri maningsih., E. Asnaryanti.,\& S.H.

Riyono. 1997. Kisaran kelimpahan dan komposisi plankton predominan di perairan kawasan timur Indonesia. P2O-LIPI. Jakarta :140 hal.

Basmi, H. J. 1998. Planktonologi (Problema Distribusi). Fakultas Perikanan dan Ilmu Kelautan Institut Pertanian Bogor, Bogor. 43 hlm

2000. Planktonologi: Plankton sebagai Indikator Kualitas Perairan. Bogor: Fakultas Perikanan dan Ilmu Kelautan, InstitutPertanian Bogor

Brower, J, E., J. H. Zar and C. Von Ende, 1990. Ekologi Umum, Metode Lapangan dan Laboratorium. Wm. C. Brown Company Publisher, Dubuque, Lowa.

Davis, C.C., 1995. The Marine and Freshwater Plankton. Michigan State University Press. $567 \mathrm{hlm}$

Fachrul, M, F., 2007. Metode Sampling Bioekologi. Bumi Aksara Jakarta.

Ferdous, Z,. dan A.K.M. Muktadir. 2009. A Review; Potenriality of Zooplankton as Bioindkator, American Journal of Applied Sciences,6: 1815-1819.

Fitraya N., H. Subakti dan R. Aryawati. 2011. Pola Sebaran Fitoplankton Serta Klorofil-a pada Bulan November di Perairan Tambelan, Laut Natuna. Laboratorium Plankton dan Produktivitas Primer, Pusat Penelitian Oseanografi LIPI, Jakarta. $8 \mathrm{hlm}$.

Hidayat, T. 2017., Kelimpahan dan Struktur Komunitas Fitoplankton pada Daerah yang di Reklamasi Pantai Seruni Kabupaten Bantaeng. Skripsi, Fakultas Ilmu Kelautan Dan Perikanan,
Universitas Hasanuddin Makasar. 76 hlm.

Humaira, R dan Zakaria, I. I. J., 2016. Komposisi dan Struktur Komunitas Zooplankton di Zona Litoral Danau Talang, Sumatera Barat. Jurusan Biologi, Fakultas Matematika dan Ilmu Pengetahuan Alam, Universitas Andalas. ISSN: 2407-8050

Hutabarat, Sahala, Soedarsono, Prijadi,Cahyaningsih dan Ina. 2013. Studi Analisa Plankton Untuk Menentukan Tingkat Pencemaran di Muara Sungai Babon Semarang. Jurnal of Manajement of aquatic resource. Vol.2(3) : 50 - $80 \mathrm{hl}$.

Hutabarat, S. dan S.M. Evans. 1986. Kunci Indentifikasi Zooplankton. Jakarta:

Universitas Indonesia.

Karuwal, J. W. Ch,. 2015. Hubungan Parameter Fisik Perairan dengan Struktur Menegak Komunitas Plankton di Teluk Ambon Dalam. Universitas Muhamadiyah Maluku Utara. ISSN : 1907-7556. $12 \mathrm{hlm}$.

Kennish, M.J. 1990. Ecology of Estuaries, Vol. II. Biological Aspecs. CRC Press. Inc Boca Raton.USA. $391 \mathrm{hlm}$.

Lasri, Desy, A., Endarwati, H., Santosa, G. W., 2013. Struktur Komunitas Zooplankton di Perairan Desa Mangurharjo Kecamatan Tugu Semarang. Jurnal of Marine Research. 2(3) : $197-204 \mathrm{hlm}$

Michael, P. 1997. Metode Ekologi Untuk Penyelidikan Ladang dan Laboratorium.

Diterjemahkan oleh Y. R. Koestoer. UI Press. Jakarta.

Nastiti, A. Sdan Hartati, S. T. 2013.Struktur Komunitas Plankton dan Kondisi Lingkungan Perairan di Teluk Jakarta. Balai Riset Pemulihan Sumber Daya Ikan. Jurnal Bawal, Vol 5 (3). 20 hlm

Nontji, A . 2008. Plankton Laut. Jakarta : LIPI Pes.

Nugraha, M. F. I., G.S. Hanafi dan Sudarto. 2008. Keanekaragaman dan Migrasi Vertikal Copepoda di Teluk Sumber Kima Bali, Jurnal Ris. Akuakultur, 3:375-383

Nybakken, J. W. 1992. Biologi Laut Suatu Pendekatan Ekologis. ( Terjemahan M. Eidiman Koesbiono . D.G., Begen, M. 
Hutomo dan S. Sukardo)PT. Gramedia.Jakarta.

Odum, E.P. 1993. Dasar-Dasar Ekologi. Edisi ketiga . Gajah mada University Press. Jogjakarta. H.459 hlm

Pranoto, B.A, Ambariyanto dan Zainuri M, 2005. Struktur Komunitas Zooplankton di Muara Sungai Serang, Jogjakarta. Jurusan Ilmu Kelautan, FPIK Universitas Diponegoro, Semarang. Vol 10 (2). $8 \mathrm{hlm}$

Setiawati, S., 2017. Komposisi dan Struktur Komunitas Zooplankton pada Kedalaman yang Berbeda di Danau Diatas Kabupaten Solok Sumatera Barat. Skripsi, Fakultas Matematika dan Ilmu Pengetahuan Alam, Universitas Andalas. $66 \mathrm{hlm}$.

Sumich, J. L. 1992. An Introduction to the Biology Of Marine Life. Wm.C. Brown Publisher

Susanti, M., 2010. Kelimpahan dan Distribusi Plankton di Perairan Waduk Kedungombo. Skripsi, Fakultas MIPA, Universitas Negeri Semarang. $46 \mathrm{hlm}$.

Umar, N.A., R.F. Kaswadji, A. Damar, I. Muchsin, dan I.W. Nurjaya. 2009. Dinamika Populasi Plankton Dalam Area Pusat Penangkapan Benur dan Nener di Perairan Pantai Kecamatan Suppa Kabupaten Pinrng, Sulawesi Selatan, Jurnal Plankton,32: 91-102

Wulandari, D. 2009. Keterkaitan antara komunitas fitoplankton dengan parameter fisika kimia di Estuari Sungai Brantas, Jawa Timur. Skripsi. Program Studi MSP. FPIK. IPB. Bogor

Yamaji, I. 1982. Ilustrasion of Marine Plankton of Japan. Hoikasha Publishing Co. Ltd. Japan. 